\title{
Influence of Zinc and Spacing on Growth and Yield of Baby Corn (Zea mays L.)
}

\author{
Sake Rajesh*, Vikram Singh, Dhananjay Tiwari, B. Venkata Sai Pratap \\ and P. Vasu Deva Reddy
}

Department of Agronomy, Sam Higginbottom University of Agriculture, Technology and sciences, Prayagraj-211007, Uttar Pradesh, India

*Corresponding author

\section{A B S T R A C T}

Keywords

Baby corn

Zea mays,

Zinc and

Spacing

Article Info

Accepted:

04 December 2020

Available Online:

10 January 2021
The Treatments consists of 3 foliar sprayings viz. $\mathrm{Zn}_{1}$ (15 DAS), $\mathrm{Zn}_{2}$ (15 \& 30 DAS $)$ and $\mathrm{Zn}_{3}(15 \& 30 \& 45), 3$ different Spacing's viz. $\mathrm{S}_{1}(40 \mathrm{~cm} \times 20$ $\mathrm{cm}), S_{2}(45 \mathrm{~cm} \times 20 \mathrm{~cm}), S_{3}(50 \mathrm{~cm} \times 20 \mathrm{~cm})$. There were 10 treatments and replicated thrice. The experiment was laid out in Randomized Block Design. The results revealed that treatment $\mathrm{ZnSO}_{4} @ 0.2 \%$ at 15 \& 30 \& 45 DAS + Spacing $45 \mathrm{~cm} \times 20 \mathrm{~cm}$ recorded maximum Plant height, dry weight, Cob yield with husk, Green fodder and B:C ratio.

\section{Introduction}

Maize, of all the cereal grains is the most highly valued for its multifarious uses, being utilized as human food, animal feed and raw materials in industry. Maize is the third most important cereal crop next to rice and wheat and has the highest production potential among the cereals. For diversification and value addition, as well as growth of food processing industries, an interesting recent development is of growing maize for vegetable purpose, which is known as 'baby corn'. It is so called because young, fresh and finger like green ears are harvested when the silk length is of $2-3 \mathrm{~cm}$ but prior to fertilization (Pandey et al., 2000). Zinc is an essential nutrient for the standard and healthy growth and development of plants. Zinc deficiency is the one of the most widespread micronutrient deficiencies in plants and cause severe reductions in crop production. Zinc plays an important role in various plant metabolism processes such as, development of cell wall, respiration, carbohydrate metabolism and gene regulation. Zinc fertilization is essential for keeping sufficient amount of available in leaf tissue (By foliar application of Zinc) which contributes the maintenance of adequate root zinc uptake. Plant spacing plays an important role in the competitive balance between the weeds and 
baby corn. The narrow row spacing limits the weed growth and increase crop yield. Close spacing leads to overcrowding and more plant competition for growth factors whereas, wider spacing reduce the plant population and enhances the vegetative growth and provide favorable condition to weed growth, thereby decreasing the total yield.

\section{Materials and Methods}

The field experiment was conducted during Zaid 2020 at CRF (Crop Research Farm). Department of Agronomy, SHUATS, Prayagraj (UP). The soil of experimental plot was sandy loam in texture, nearly neutral in soil reaction $(\mathrm{pH} 7.3)$, low in organic carbon $(0.57 \%)$, available $\mathrm{N}(230 \mathrm{~kg} / \mathrm{ha})$, available $\mathrm{P}$ $(32.10 \mathrm{~kg} / \mathrm{ha})$ and available $\mathrm{K}(346 \mathrm{~kg} / \mathrm{ha})$. The Treatments consists of 3 foliar sprayings viz. $\mathrm{Zn}_{1}$ (15 DAS), $\mathrm{Zn}_{2}$ (15 \& 30 DAS) and $\mathrm{Zn}_{3}$ (15 \& $30 \& 45), 3$ different Spacing's viz. $\mathrm{S}_{1}(40 \mathrm{~cm} \times 20 \mathrm{~cm}), \mathrm{S}_{2}(45 \mathrm{~cm} \times 20 \mathrm{~cm}), \mathrm{S}_{3}(50$ $\mathrm{cm} \times 20 \mathrm{~cm}$ ) viz: whose effect is observed on Baby corn (var. G5414). There were 10 treatments and replicated thrice. The crop was sown on $2^{\text {nd }}$ August 2020 using variety G5414 with a seed rate of $20 \mathrm{~kg} / \mathrm{ha}$. The recommended dose of $120 \mathrm{~kg} \mathrm{~N}, 60 \mathrm{~kg} \mathrm{P}, 40$ $\mathrm{kg} \mathrm{K} \mathrm{K}_{2} \mathrm{O} \& 10 \mathrm{~kg} \mathrm{Zn}$ per ha was applied. Foliar spray of $\mathrm{Zn}$ was applied according to the treatment details through $\mathrm{ZnSO}_{4}$.

\section{Results and Discussion}

Data presented in Table 1 revealed that plant height was observed with the application of Foliar spray of ZnSO4 @ $0.2 \%$ at $15 \& 30$ \& 45 DAS + Spacing $45 \mathrm{~cm} \times 20 \mathrm{~cm}(169.40$ $\mathrm{cm})$ which was significantly higher over rest of the treatments except Foliar spray of ZnSO4 @ $0.2 \%$ at $15 \& 30$ DAS + Spacing $50 \mathrm{~cm} \times 20 \mathrm{~cm}(151.67 \mathrm{~cm})$, Foliar spray of ZnSO4 @ $0.2 \%$ at $15 \& 30 \& 45$ DAS + Spacing $40 \mathrm{~cm} \times 20 \mathrm{~cm}(159.0 \mathrm{~cm})$, Foliar spray of ZnSO4 @ $0.2 \%$ at $15 \& 30 \& 45$
DAS + Spacing $50 \mathrm{~cm} \times 20 \mathrm{~cm}(164.23 \mathrm{~cm})$ which are statistically at par. This may be due to the favourable influence of the micronutrient on the growth of baby corn might be due to rapid cell division and cell elongation with balanced nutrient (NPK) supply. Variable plant height was found due to differences in crop geometry in maize, Rakesh Kumar and Bohra (2014).

Data presented in Table 1 revealed that Plant dry weight(g/plant) was higher in Foliar spray of $\mathrm{ZnSO}_{4} @ 0.2 \%$ at 15 \& 30 \& 45 DAS + Spacing $45 \mathrm{~cm} \times 20 \mathrm{~cm}(132.00 \mathrm{~g})$ which was significantly superior over rest of the treatments and lowest was obtained in Foliar spray of $\mathrm{ZnSO}_{4} @ 0.2 \%$ at 15 \& $30 \mathrm{DAS}+$ Spacing $40 \mathrm{~cm} \times 20 \mathrm{~cm}(68.67 \mathrm{~g})$. The possible reason for this might be due to the fact that the favourable increase in dry weight of baby corn might be due to Zinc involvement in auxin synthesis which played a major role in photosynthetic activity of the crop (as in other $\mathrm{C}_{4}$ plants) Amutham et al., 2019.

Data presented in Table 1 maximum yield with husk (10.11 t/ha) was observed in Foliar spray of $\mathrm{ZnSO}_{4} @ 0.2 \%$ at $15 \& 30 \& 45$ DAS + Spacing $45 \mathrm{~cm} \times 20 \mathrm{~cm}$ which is significantly superior over rest of the treatments except Foliar spray of $\mathrm{ZnSO}_{4}$ @ $0.2 \%$ at $15 \& 30 \& 45$ DAS + Spacing $40 \mathrm{~cm}$ $\times 20 \mathrm{~cm}(8.95 \mathrm{t} / \mathrm{ha})$, Folia r spray of $\mathrm{ZnSO}_{4} @$ $0.2 \%$ at $15 \& 30 \& 45$ DAS + Spacing $50 \mathrm{~cm}$ $\times 20 \mathrm{~cm}(9.25 \mathrm{t} / \mathrm{ha})$ which are statistically at par.

Foliar application of $\mathrm{ZnSO}_{4}$ led to increase in the cob yield by $10 \%$ to $35 \%$ over control no Zinc yield is an ultimate end product of many yield contributing components, physiological and morphological process taking place in plants during growth and development Mona, (2015). 
Table.1 Influence of zinc and spacing on growth and yield of baby corn (Zea mays L.)

\begin{tabular}{|c|c|c|c|c|c|}
\hline Treatment & $\begin{array}{l}\text { Plant } \\
\text { height at } \\
\text { harvest } \\
(\mathrm{cm})\end{array}$ & $\begin{array}{c}\text { Dry } \\
\text { weight } \\
\text { g/plant at } \\
\text { harvest }\end{array}$ & $\begin{array}{l}\text { Yield with } \\
\text { husk(t/ha) }\end{array}$ & $\begin{array}{c}\text { Green } \\
\text { fodder(t/ha) }\end{array}$ & $\begin{array}{l}\mathrm{B}: \mathrm{C} \\
\text { ratio }\end{array}$ \\
\hline Control (standard spacing) + RDF & 102.30 & 80.33 & 6.88 & 29.00 & 1.00 \\
\hline Foliar spray of $\mathrm{ZnSO}_{4} @ 0.2 \%$ at $15 \mathrm{DAS}+$ Spacing $40 \mathrm{~cm} \times 20 \mathrm{~cm}$ & 112.70 & 77.67 & 7.21 & 30.67 & 1.15 \\
\hline Foliar spray of $\mathrm{ZnSO}_{4} @ 0.2 \%$ at $15 \mathrm{DAS}+$ Spacing $45 \mathrm{~cm} \times 20 \mathrm{~cm}$ & 117.10 & 86.33 & 7.88 & 32.00 & 1.28 \\
\hline Foliar spray of $\mathrm{ZnSO}_{4} @ 0.2 \%$ at $15 \mathrm{DAS}+$ Spacing $50 \mathrm{~cm} \times 20 \mathrm{~cm}$ & 117.90 & 78.67 & 8.27 & 37.00 & 1.46 \\
\hline Foliar spray of $\mathrm{ZnSO}_{4} @ 0.2 \%$ at $15 \& 30 \mathrm{DAS}+$ Spacing $40 \mathrm{~cm} \times 20 \mathrm{~cm}$ & 133.50 & 68.67 & 7.71 & 31.33 & 1.16 \\
\hline Foliar spray of $\mathrm{ZnSO}_{4} @ 0.2 \%$ at $15 \& 30 \mathrm{DAS}+$ Spacing $45 \mathrm{~cm} \times 20 \mathrm{~cm}$ & 149.30 & 73.33 & 8.11 & 35.00 & 1.31 \\
\hline Foliar spray of $\mathrm{ZnSO}_{4} @ 0.2 \%$ at $15 \& 30 \mathrm{DAS}+$ Spacing $50 \mathrm{~cm} \times 20 \mathrm{~cm}$ & 151.67 & 92.33 & 8.15 & 35.67 & 1.34 \\
\hline Foliar spray of $\mathrm{ZnSO}_{4} @ 0.2 \%$ at $15 \& 30 \& 45 \mathrm{DAS}+$ Spacing $40 \mathrm{~cm} \times 20 \mathrm{~cm}$ & 159.10 & 96.00 & 8.95 & 38.00 & 1.42 \\
\hline Foliar spray of $\mathrm{ZnSO}_{4} @ 0.2 \%$ at $15 \& 30 \& 45 \mathrm{DAS}+$ Spacing $45 \mathrm{~cm} \times 20 \mathrm{~cm}$ & 169.40 & 132.00 & 10.11 & 43.33 & 1.80 \\
\hline Foliar spray of $\mathrm{ZnSO}_{4} @ 0.2 \%$ at $15 \& 30 \& 45 \mathrm{DAS}+$ Spacing $50 \mathrm{~cm} \times 20 \mathrm{~cm}$ & 164.23 & 106.33 & 9.25 & 40.67 & 1.62 \\
\hline $\operatorname{SEm}( \pm)$ & 6.00 & 3.35 & 0.40 & 2.54 & - \\
\hline $\mathrm{CD}(\mathbf{P}=\mathbf{0 . 0 5})$ & 17.81 & 9.94 & 1.19 & 7.54 & - \\
\hline
\end{tabular}


Data presented in Table 1 revealed that maximum green fodder yield (43.33 t/ha) was observed in Foliar spray of $\mathrm{ZnSO}_{4} @ 0.2 \%$ at $15 \& 30 \& 45$ DAS + Spacing $45 \mathrm{~cm} \times 20 \mathrm{~cm}$ which is significantly superior over rest of the treatments except Foliar spray of $\mathrm{ZnSO}_{4}$ @ $0.2 \%$ at $15 \& 30 \& 45$ DAS + Spacing $50 \mathrm{~cm}$ $\times 20 \mathrm{~cm}$ (40.67 t/ha) and Foliar spray of $\mathrm{ZnSO}_{4} @ 0.2 \%$ at $15 \& 30 \& 45 \mathrm{DAS}+$ Spacing $40 \mathrm{~cm} \times 20 \mathrm{~cm}(38.00 \mathrm{t} / \mathrm{ha})$.

Increase in a green fodder yield might be due to the enhanced translocation of photosynthates with applied Zinc, which resulted in a higher production of green fodder in a respective level of nutrient. Similar results of significantly higher fodder yield with $\mathrm{Zn}$ application was also reported by Mahdi et al., 2012.

Data presented in Table 1 revealed that B:C Ratio was obtained for Foliar spray of $\mathrm{ZnSO}_{4}$ @ $0.2 \%$ at $15 \& 30 \& 45 \mathrm{DAS}+$ Spacing 45 $\mathrm{cm} \times 20 \mathrm{~cm}(1.80)$ which is significantly superior over rest of the treatments. Increase in gross returns, net returns and benefit cost ratio due to higher baby corn yield and green fodder yield. Increase in gross returns, net returns and benefit cost ratio due to higher baby corn yield and green fodder yield. These results are positively corroborating with findings of Rakesh Kumar and Bohra (2014).

Based on the findings, of this experiment can be concluded that treatment with Foliar spray of $\mathrm{ZnSO}_{4} @ 0.2 \%$ at $15 \& 30$ \& 45 DAS + Spacing $45 \mathrm{~cm} \times 20 \mathrm{~cm}$ is the best and economically profitable. Spraying of (Foliar spray of $\mathrm{ZnSO}_{4} @ 0.2 \%$ at $15 \& 30 \& 45$ DAS + Spacing $45 \mathrm{~cm} \times 20 \mathrm{~cm}$ is profitable for farmers.

\section{Acknowledgement}

I express gratitude to my advisor Dr.Vikram Singh for constant support and guideline. And also, all the faculty members of SHUATS for inspiration.

\section{References}

Das S., Ghosh G., Kaleem MD., and Bahadur V. (2009). Effect of different levels of nitrogen and crop geometry on the growth, yield and quality of baby corn (Zea mays L.). International symposium on the Socio-Economic Impact of Modern Vegetable Production Technology in Tropical Asia 10.17660/ Acta Hortic.2009.

Estzer Muryani. (2014). Effect of Plant Density and Row Spacing on Maize (Zea mays L.) Grain Yield in Different Crop Year Journal of Agricultural and Environmental Sciences Vol. 2, No.1 (2015).

Hussain B., Afzal M., Shahab Q., Abbas N., Hussain, S. W., Zehra Q., Hussain A., Hussain Z., Ali A., and Abbas, Y. 2016. Effect of different methods of zinc application on maize (Zea mays). International Journal of Agronomy and Agricultural Research, 9(3):66-75.

Kamani M.D., Ardeshna R. B., Ghetiya K.P., Gohil J.R., and Raiyani V. N. (2014). Effect of Row Spacing and Weed Management Practices on Growth and Yield of Summer Maize (Zea mays L.). Int. J. Pure App. Biosci. 7 (2): 58-64 (2019).

Mahdhi SS, Hysain B, Singh L. Influence of seed rate, nitrogen and Zinc on fodder maize (Zea mays) in temperate condition of western Himalayas. Indian journal of Agronomy. 2012; 57(1):85-88.

Mona EA. Increasing $\mathrm{Zn}$ ratio in a compound foliar NPK fertilizer in relation to growth, yield and quality of corn plant. Journal of innovations in Pharmaceuticals and biological Sciences. 2015; 2(4):451-468. 
Pandey, A.K., Prakash, V., Mani, V.P. And Singh, R.D., 2000, Effect of rate of nitrogen and time of application on yield and economics of Baby corn. Indian J. Agron., 45(2): 338-343.

Rakesh kumar, Bohra JS. Effect of NPKS and
Zn application on growth, yield, economics and quality of baby corn. Archives Agron. Soil Sci. 2014; 60(9):1193- 1206.

\section{How to cite this article:}

Sake Rajesh, Vikram Singh, Dhananjay Tiwari, B. Venkata Sai Pratap and Vasu Deva Reddy, P. 2021. Influence of Zinc and Spacing on Growth and Yield of Baby Corn (Zea mays L.). Int.J.Curr.Microbiol.App.Sci. 10(01): 434-438. doi: https://doi.org/10.20546/ijcmas.2021.1001.053 